\title{
Resource Limitations Influence Growth and Vigor of Idaho Fescue, a Common Understory Species in Pacific Northwest Ponderosa Pine Forests
}

\author{
Craig A. Carr ${ }^{1, *}$ and William C. Krueger ${ }^{2}$ \\ 1 Department of Animal and Range Sciences, Montana State University, PO Box 172900, Bozeman, \\ MT 59717, USA \\ 2 Department of Animal and Rangeland Sciences, Oregon State University, 112 Withycombe Hall, Corvallis, \\ OR 97331, USA; william.c.krueger@oregonstate.edu \\ * Correspondence: craig.carr@montana.edu; Tel.: +1-406-994-3282
}

Academic Editors: Brian J. Palik and Timothy A. Martin

Received: 13 October 2016; Accepted: 16 December 2016; Published: 22 December 2016

\begin{abstract}
Alterations in under-canopy resource availability associated with elevated ponderosa pine (Pinus ponderosa Dougl.) abundance can negatively influence understory vegetation. Experimental evidence linking under-canopy resource availability and understory vegetation is scarce. Yet this information would be beneficial in developing management strategies to recover desired understory species. We tested the effects of varying nitrogen $(\mathrm{N})$ and light availability on Idaho fescue (Festuca idahoensis Elmer), the dominant understory species in ponderosa pine/Idaho fescue plant associations in eastern Oregon. In a greenhouse experiment, two levels of $\mathrm{N}\left(50 \mathrm{~kg} \cdot \mathrm{N} \cdot \mathrm{ha}^{-1}\right.$ and $0 \mathrm{~kg} \cdot \mathrm{N} \cdot \mathrm{ha}^{-1}$ ) and shade ( $80 \%$ shade and $0 \%$ shade) were applied in a split-plot design to individual potted plants grown in soil collected from high abundance pine stands. Plants grown in unshaded conditions produced greater root $(p=0.0027)$ and shoot $(p=0.0017)$ biomass and higher cover values $(p=0.0378)$ compared to those in the shaded treatments. The addition of $\mathrm{N}$ had little effect on plant growth ( $p=0.1602,0.5129$, and 0.0853 for shoot biomass, root biomass, and cover, respectively), suggesting that soils in high-density ponderosa pine stands that lack understory vegetation were not $\mathrm{N}$ deficient and Idaho fescue plants grown in these soils were not $\mathrm{N}$ limited. Management activities that increase under-canopy light availability will promote the conditions necessary for Idaho fescue recovery. However, successful restoration may be constrained by a lack of residual fescue or the invasion of more competitive understory vegetation.
\end{abstract}

Keywords: ponderosa pine; Idaho fescue; overstory-understory interactions; nitrogen; light availability

\section{Introduction}

In ponderosa pine (Pinus ponderosa Dougl.) forests, understory herbaceous vegetation is important for maintaining soil stability, site hydrology, and nutrient dynamics, it provides important wildlife habitat and livestock forage, and it is a major component of the fire regime, natural variability, and aesthetic value of these ecosystems. Since European settlement, many ponderosa pine forests have undergone a substantial structural change, moving from open-canopy, low-density, older-aged forests to high-density, closed-canopy, younger forests, primarily in response to increases in the fire return interval [1,2]. Along with overstory alterations, reductions in herbaceous understory growth, biomass, and vigor have occurred, and in many cases, ponderosa pine stands have experienced losses of important understory species [3-8]. Management of ponderosa pine forests toward a structure that more closely resembles presettlement conditions is often prescribed, however, many restoration programs focus on the manipulation of overstory structure without consideration of the treatment 
effects on understory species. Understory dynamics should also be considered in ponderosa pine restoration activities [9].

Although existing research has provided insight into the mechanisms associated with understory vegetation response to altered pine abundance [6,10-13], the results have been inconsistent and have not addressed climax Pacific Northwest ponderosa pine stands, therefore a complete understanding of the management needs in these forests is lacking. Carr and Krueger [3] observed reductions in under-canopy light and nitrogen availability associated with increasing tree abundance in a case study of a ponderosa pine forest in the Pacific Northwest, however no experimental evidence linking under-canopy resource availability to understory vegetation dynamics was available. Thus, we initiated an experiment designed to corroborate observational data and evaluate if under-canopy light and nitrogen availability influence the growth and vigor of understory vegetation and to consider the implications for the management of Pacific Northwest ponderosa pine forests. We selected the perennial bunchgrass Idaho fescue (Festuca idahoensis Elmer) for this study as it is the dominant understory species in ponderosa pine/Idaho fescue plant associations in eastern Oregon [14] and has been shown to decline significantly under conditions of high ponderosa pine abundance [3].

\section{Materials and Methods}

A greenhouse experiment designed to test the effects of variable light and $\mathrm{N}$ availability on Idaho fescue growth rate, biomass, and vigor was conducted over 83 days spanning 11 April through 3 July 2007.

\subsection{Field Protocol}

Idaho fescue plants were collected in early April from a ponderosa pine stand in eastern Oregon $\left(44^{\circ} 12^{\prime} 52^{\prime \prime} \mathrm{N}, 118^{\circ} 59^{\prime} 16^{\prime \prime} \mathrm{W}\right)$. The site was located at $1500 \mathrm{~m}$ elevation and situated in an area of gently sloping ( $\sim 8 \%$ slope gradient) north-facing hillsides. The average daily high and low summer and winter temperatures, recorded between 1971 and 2000 at Seneca, Oregon $(\sim 8 \mathrm{~km}$ south of the study area) were $24^{\circ} \mathrm{C}$ and $1.5{ }^{\circ} \mathrm{C}$, and $4{ }^{\circ} \mathrm{C}$ and $-9{ }^{\circ} \mathrm{C}$, respectively [15]. Approximately $32 \mathrm{~cm}$ of precipitation is received annually, most occurring in the winter months and primarily in the form of snow [15]. Soils of the area were composed of an ash mantle overlaying serpentinite gravel and cobble and were classified as fine-loamy, mixed, superactive, and frigid Vitrandic Haploxerolls. The site exhibited an open canopy structure that was relatively free of trees. The adjacent forest was composed primarily of small-diameter ponderosa pine trees $(15-20 \mathrm{~cm}$ diameter at $1.4 \mathrm{~m}$ height) growing at a density of approximately 260 trees $\cdot \mathrm{ha}^{-1}$. Idaho fescue plants $(2-3 \mathrm{~cm}$ basal diameter) were removed to a depth of $10 \mathrm{~cm}$ using a $5.08 \mathrm{~cm}$ diameter soil core centered on the plant and then placed in a container of native soil for transportation to the greenhouse where they were replanted into $3.79 \mathrm{~L}$ pots. Prior to replanting, the foliage of each plant was clipped at a height of $5 \mathrm{~cm}$ and the soil below $5 \mathrm{~cm}$ depth was removed.

Soil from a dense ponderosa pine stand ( 2800 trees $\cdot \mathrm{ha}^{-1}$ ) neighboring the location of the Idaho fescue harvest was used for potting media. This soil was selected because it represented the soil conditions of high pine density stands that lack the characteristic perennial bunchgrass dominated understory. This soil provided the baseline soil conditions from which increasing plant resource availability would provide insight into potential nutrient limitations for understory vegetation growth in severely degraded under-canopy environments. The soil was harvested to a depth of $10 \mathrm{~cm}$ (mineral soil) and prior to potting the soil was uniformly mixed and passed through a $7 \mathrm{~mm}$ screen to remove rocks, litter, and root fragments.

\subsection{Greenhouse Protocol and Experimental Design}

Potted Idaho fescue plants were grown in a greenhouse located on the Oregon State University campus at Corvallis, Oregon $\left(44^{\circ} 34^{\prime} 12^{\prime \prime} \mathrm{N}, 123^{\circ} 16^{\prime} 48^{\prime \prime} \mathrm{W}\right)$. The average daytime (06:00-20:00 h) temperature of the greenhouse throughout the study was $23.7^{\circ} \mathrm{C}(\mathrm{SD}=2.19)$. 
Two levels of shade and $\mathrm{N}$ were applied in a split plot design. Whole plots $(80 \%$ shade or $0 \%$ shade) were randomly assigned to greenhouse bench locations (replications) and subplots $\left(50 \mathrm{~kg} \cdot \mathrm{N} \cdot \mathrm{ha}^{-1}\right.$ or $0 \mathrm{~kg} \cdot \mathrm{N} \cdot \mathrm{ha}^{-1}$ ) were randomly assigned to two pots randomly allocated within each whole plot. Five replications of each treatment combination were performed.

Shade treatments were applied using tents made of $80 \%$ shade cloth draped over a $76 \mathrm{~cm} \times 76 \mathrm{~cm}$ $\times 76 \mathrm{~cm}$ polyvinyl chloride (PVC) pipe frame. Eighty percent shade represented the average canopy closure (79.14\%) observed in the field location for high density pine stands that lack characteristic perennial bunchgrass dominated vegetation [3].

Urea (46-0-0) was applied at $50 \mathrm{~kg} \cdot \mathrm{N} \cdot \mathrm{ha}^{-1}$ to each pot selected for $\mathrm{N}$ treatment. Urea pellets were covered with soil and watered-in to prevent $\mathrm{N}$ loss through ammonia $\left(\mathrm{NH}_{3}\right)$ volatilization. Fifty $\mathrm{kg} \cdot \mathrm{N} \cdot \mathrm{ha}^{-1}$ was deemed adequate to meet the needs of eastern Oregon Idaho fescue. A plant tissue $\mathrm{N}$ content of $2 \%-5 \%$ (dry weight) is required for optimal plant growth [16] and the average dry weight biomass of Idaho fescue in ponderosa pine/Idaho fescue plant associations is $365 \mathrm{~kg} \cdot \mathrm{ha}^{-1}$ [14], therefore, approximately $7.3-18.25 \mathrm{~kg} \cdot \mathrm{ha}^{-1}$ was needed to support typical growth of Idaho fescue in the region of our field sites. We used $50 \mathrm{~kg} \cdot \mathrm{N} \cdot \mathrm{ha}^{-1}$ to ensure that $\mathrm{N}$ supply was not limiting and to allow for some $\mathrm{N}$ loss through leaching. All pots were kept moist throughout the experiment with regular watering.

Pretreatment Idaho fescue size, indexed by the product of the length of the longest axis through the base of the plant and the axis perpendicular to the longest axis, was measured for use as a covariate in the analyses. Measurements of plant height and foliar cover were performed weekly and biweekly, respectively. Plant height values used in these analyses were averages of the shortest, tallest, and two intermediate length leaves. Foliar cover was evaluated using downward looking digital photographs of each plant. A digital grid of 3400 uniformly spaced dots was overlaid on each digital photo in ArcMap version 9.1 [17]. The number of points touching the leaf material was tallied for each plant and used as an index of foliar cover. Images were acquired using a Nikon Coolpix 950 digital camera (Nikon Corporation, Tokyo, Japan) mounted $1 \mathrm{~m}$ above the ground on a PVC frame modified from Louhaichi et al. [18]. This set up along with the uniform focal length $(7.2 \mathrm{~mm})$ and resolution $(1200 \times 1600$ pixels $)$ for each photo provided standard image dimensions of $89 \mathrm{~cm} \times 67 \mathrm{~cm}$ with a pixel size of $0.56 \mathrm{~mm}$. At the end of the experiment, shoot and root biomass were measured. Plants were clipped at ground level and all leaf material weighed after drying for $48 \mathrm{~h}$ at $60^{\circ} \mathrm{C}$. Root material was collected by passing the potting media through a $7 \mathrm{~mm}$ screen and then washing the remaining material through a $0.59 \mathrm{~mm}$ (\#30) sieve. The residual root material was dried for $48 \mathrm{~h}$ at $60{ }^{\circ} \mathrm{C}$ and then weighed. Three shoot biomass samples measured below the resolution of the scale were used to weigh the samples $(0.1 \mathrm{~g})$. To provide a value for trace biomass, $0.09 \mathrm{~g}$ was used in the analyses.

Analyses of shoot biomass, root biomass, final shoot length, and final cover were performed using PROC MIXED [19]. Random effects for replication and whole plot were included in the model along with the fixed effects of the shade and $N$ treatments and their interaction. Root and shoot biomass values were log transformed prior to analysis to better meet the assumptions associated with ANOVA analyses.

The responses of foliar cover and leaf length over time were evaluated using PROC MIXED [19]. The models included fixed effects for shade, $\mathrm{N}$, date, and their interactions, and random effects for replication, whole plot, and subplot and covariance structures selected to best model the within plant variability associated with the repeated measures nature of the experiment [20]. Because of a consistent lack of significance of the three-way interaction among shade, $\mathrm{N}$, and date, and two-way interaction between shade and $\mathrm{N}$, models for both responses were reduced to the main effects of shade, $\mathrm{N}$, and date, and the interactions between shade and date and $\mathrm{N}$ and date. To meet the assumptions of equal variance both the cover and leaf length data were log transformed prior to analyses. 


\section{Results}

The only statistically significant effect in the analyses of shoot biomass, root biomass, shoot length, and foliar cover was associated with the shade treatment (Table 1). Plants growing under shade had lower shoot and root biomass and foliar cover and exhibited longer shoot lengths compared to those plants growing in the un-shaded conditions (Figure 1). Although $\mathrm{N}$ addition appeared to show a positive trend in all responses (Figure 1), the effect was not statistically significant.

Table 1. F statistics and $p$-values from Type III tests of the fixed effects of shade, nitrogen, and shade and nitrogen interaction from mixed effects models with response variables of Idaho fescue shoot and root weight, final shoot length, and final plant cover.

\begin{tabular}{ccccccc}
\hline & \multicolumn{2}{c}{ Shade } & \multicolumn{2}{c}{ Nitrogen } & \multicolumn{2}{c}{ Shade * Nitrogen } \\
\hline & $\boldsymbol{F}$ & $\boldsymbol{p}$-Value & $\boldsymbol{F}$ & $\boldsymbol{p}$-Value & $\boldsymbol{F}$ & $\boldsymbol{p}$-Value \\
\hline Shoot Weight & 56.61 & 0.0017 & 2.40 & 0.1602 & 1.10 & 0.3244 \\
Root Weight & 433.46 & 0.0027 & 0.47 & 0.5129 & 0.10 & 0.7567 \\
Final Length & 50.19 & 0.0021 & 2.57 & 0.1478 & 0.03 & 0.8596 \\
Final Cover & 9.35 & 0.0378 & 3.85 & 0.0853 & 0.02 & 0.8932 \\
\hline
\end{tabular}
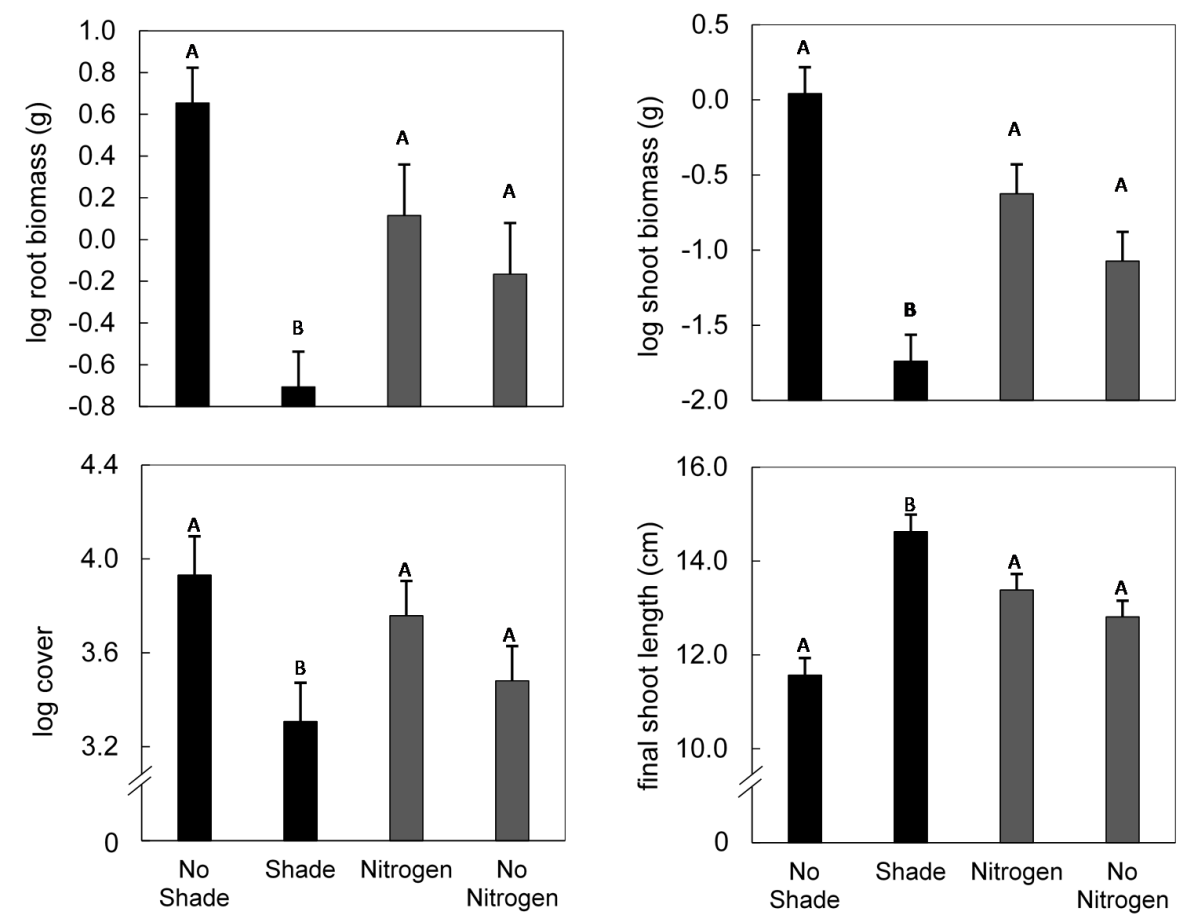

Figure 1. The effects of shade and nitrogen treatments on Idaho fescue shoot biomass, root biomass, shoot length, and cover. Columns represent group least squares means while error bars. Differing letters represent differences within treatment groups at the $p<0.05$ level

When including time as a factor in the analyses of shoot length, the main effect of shade remained significant while differences in shoot length over time in response to $\mathrm{N}$ addition were also apparent (Table 2). No interaction between shade and $\mathrm{N}$ was evident, however significant interactions between shade and time and $\mathrm{N}$ and time were evident (Table 2). The change in shoot length over time tended to follow a curvilinear pattern showing rapid elongation in early growth and stabilizing as maximum shoot length was approached in the later weeks of the experiment (Figure 2). Differences in shoot length among shade treatment groups were not evident in the first 2 weeks of growth, however the subsequent time periods showed successive increases in shoot length in the shaded treatment (Figure 2). The addition of $\mathrm{N}$ stimulated an increase in the early rate of leaf elongation as significant 
differences among $\mathrm{N}$ treatment groups occurred in weeks 2 through 5 . However, by the end of the study, plants in the unfertilized treatment had shoot lengths that equaled that of the fertilized plants (Figure 2).

Table 2. F statistics and P-values from Type III tests of the fixed effects of shade, nitrogen, time, and the interaction effects of shade and time and nitrogen and time from mixed effects models with response variables of Idaho fescue shoot length and foliar cover.

\begin{tabular}{ccccccccccc}
\hline & \multicolumn{2}{c}{ Shade } & \multicolumn{2}{c}{ Nitrogen } & \multicolumn{2}{c}{ Time } & \multicolumn{2}{c}{ Shade *Time } & \multicolumn{2}{c}{ Nitrogen * Time } \\
\hline & $\boldsymbol{F}$ & $\boldsymbol{p}$-Value & $\boldsymbol{F}$ & $\boldsymbol{p}$-Value & $\boldsymbol{F}$ & $\boldsymbol{p}$-Value & $\boldsymbol{F}$ & $\boldsymbol{p}$-Value & $\boldsymbol{F}$ & $\boldsymbol{p}$-Value \\
\hline Length & 29.19 & 0.0001 & 7.50 & 0.0169 & 295.16 & $<0.0001$ & 10.36 & $<0.0001$ & 3.50 & 0.0006 \\
Cover & 3.57 & 0.1309 & 5.61 & 0.0422 & 183.57 & $<0.0001$ & 5.63 & 0.0009 & 4.13 & 0.0059 \\
\hline
\end{tabular}

Including time in the analysis of foliar cover indicated significant effects of the interactions between $\mathrm{N}$ and time and shade and time. The main effect of $\mathrm{N}$ was weak while the main effect of shade was nonsignificant (Table 2). Plant cover change over time generally followed a curvilinear pattern with rapid increase in foliar cover through the early portion of the experiment followed by a much reduced rate of increase toward the end of the trial (Figure 2). Differences in Idaho fescue cover among shade treatment groups were not evident in the first 6 weeks of the experiment, however the subsequent two measurements, in week 7 and week 9, indicated successive increases in plant cover and identified unshaded plants as eventually accumulating greater plant cover compared to shaded individuals (Figure 2). The addition of $\mathrm{N}$ stimulated an increase in foliar cover earlier in the experiment as significant differences among $\mathrm{N}$ treatment groups occurred in weeks 3 and 5 (Figure 2). However, by the end of the experiment, plants in the un-fertilized treatment had foliar cover values that rivaled that of the fertilized plants (Figure 2).
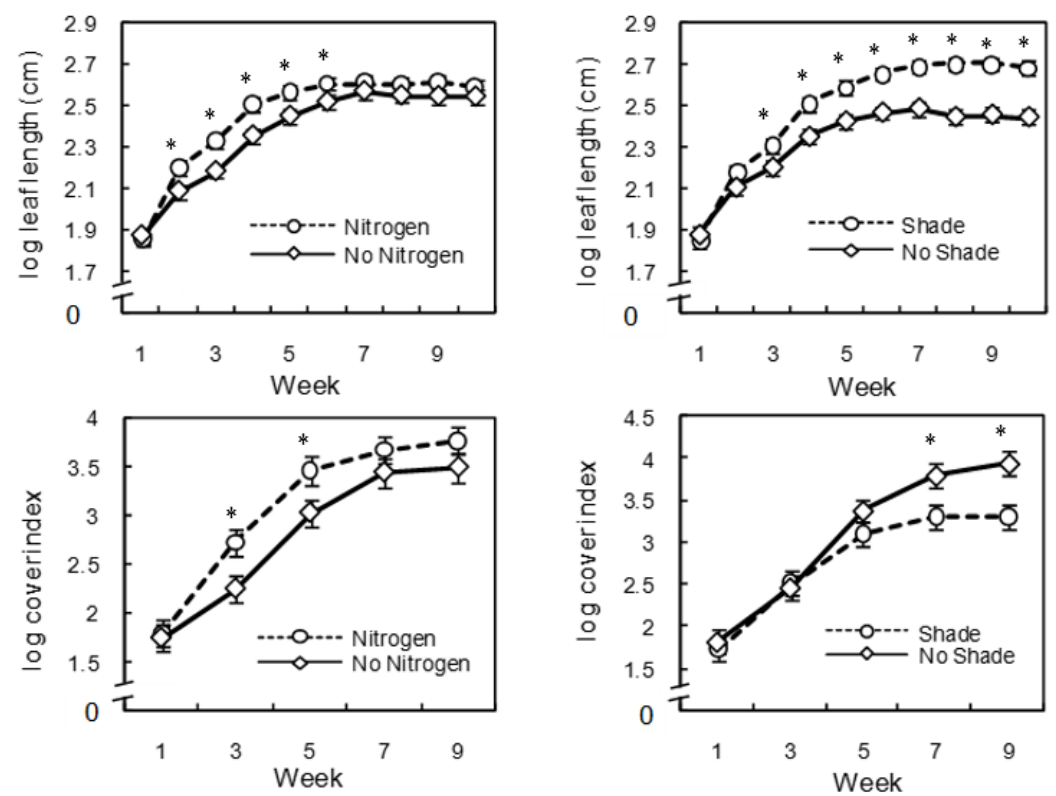

Figure 2. The effects of shade and nitrogen treatments on Idaho fescue leaf length and foliar cover. Dots represent the nitrogen or shade treatment group least squares means at each time interval while error bars are \pm 1 standard error. Length was measured weekly throughout the experiment while cover was measured bi-weekly. Although not continuous data, lines between data points display the interaction between treatments and time. Significant differences $(p<0.05)$ within time periods are identified by * 


\section{Discussion}

It was apparent from these analyses that Idaho fescue plants grew larger under high light intensity environments. Plants in the unshaded treatments exhibited higher shoot and root biomass and larger cover indices than those in the shaded environments. Plants commonly exhibit greater biomass and growth when developing under high irradiance [21,22] and others have observed decreases in biomass of ponderosa pine forest understory vegetation when grown under shaded conditions $[4,10,23]$. Approximately $40 \%$ of plant dry matter comes from carbon fixed through photosynthesis [24], therefore changes in plant biomass may be attributed to changes in the photosynthetic activity of the plant. Although numerous factors can affect photosynthesis including light, temperature, water, $\mathrm{CO}_{2}$ availability, and plant health and age [25], it was evident that light availability influenced the photosynthetic ability of the Idaho fescue plants used in this experiment. The light saturation point for a plant is reached when carbon fixation and photosynthetic activity is maximized and further increases in light intensity do not generate associated increases in photosynthetic activity. Coyne et al. [25] indicated the light saturation point for $\mathrm{C}_{3}$ species, such as Idaho fescue, is around $50 \%$ of full sunlight. Our $80 \%$ shade treatment corresponded to a photosynthetically active radiation intensity approximately $22 \%$ of that experienced in the un-shaded treatments [26] and therefore substantially lower than the light saturation point.

The increase in leaf length observed in the shaded treatments is a common response to low irradiance environments and is a leaf-level adaptation that increases leaf area $[21,22,27]$. Leaf elongation is one of several plant morphological and physiological adaptations associated with conservative resource use that promotes efficient light energy capture while reducing respiratory losses [22,28,29]. These changes enable plants to maintain a positive carbon balance under conditions of limited carbon input brought on by the diminished light energy availability [28].

The shade effect on leaf length was consistent over time with the exception of the first two measurement periods, although divergence in leaf length was evident by week 2 . Plants in the shaded treatment exhibited longer leaf lengths over weeks 3-10. The lack of a significant shade effect over the first 2 weeks was likely a reflection of the period of plant growth initiation.

There was also a lag period prior to observing a significant difference in foliar cover between plants in the two shade treatment groups. It appears as though initial rates of increase in foliar cover were similar, however at around week 5 , the plants in the shaded treatment substantially reduced the rate of increase in cover while those in the un-shaded group continued with a strong growth rate. The decline in the growth rate of shaded plants was likely related to the inability of these plants to fix carbon at a rate required to support further growth [24].

Longer leaves were evident in plants subjected to the $\mathrm{N}$ addition treatment during weeks 2-6, indicating that leaf growth rate was higher under the $\mathrm{N}$ treatment during this time period. As this was not a persistent effect and final leaf length did not differ among $\mathrm{N}$ treatment groups, it is likely that this temporal effect was related to increased mineral $\mathrm{N}$ supply to the plants in the fertilized treatments. Mechanisms associated with root-nutrient contact including mass transport, diffusion, and root interception are enhanced under conditions of higher soil nutrient concentrations [30]. Therefore, plants in the fertilized treatment were able to acquire the $\mathrm{N}$ needed to meet their growth needs at a faster rate than those in the un-fertilized treatments simply as a function of increased $\mathrm{N}$ availability associated with higher soil concentrations.

Nitrogen addition also appeared to stimulate a short-term increase in the growth rate, as indexed by cover, of Idaho fescue plants. Plants in the $\mathrm{N}$ addition treatment expressed larger foliar cover values than those in the un-fertilized group during weeks 3,5, and 7. Cover values from the two groups were statistically similar in earlier (i.e., week 1 ) and later (week 9) time periods. This pattern was similar to the growth rate indexed by leaf elongation and was also likely in response to increased availability of mineral $\mathrm{N}$ at the root-soil interface associated with elevated soil $\mathrm{N}$ concentrations in the fertilized treatment. The unfertilized plants were eventually able to accumulate enough $\mathrm{N}$ to meet 
their growth requirements as foliage cover values for both $\mathrm{N}$ treatment groups were similar by the end of the experiment.

The general lack of a lasting $\mathrm{N}$ effect on Idaho fescue growth indicated that soils from dense ponderosa pine forests were not $\mathrm{N}$ deficient and Idaho fescue plants grown in these soils were not $\mathrm{N}$ limited. Although others have reported decreases in net $\mathrm{N}$ mineralization associated with increasing ponderosa pine abundance [23,31], the reduction may not have a substantial effect on the growth of desired understory species. In our study, soils were sieved prior to use to remove all litter and coarse organic material which likely reduced the potential for $\mathrm{N}$ immobilization and this may explain why $\mathrm{N}$ mineralization rates were high enough to support vigorous plant growth, even in un-fertilized treatments. Kaye et al. [32] reported similar findings to ours where increased net $\mathrm{N}$ mineralization associated with restoration treatments in formerly dense ponderosa pine stands did not correspond to increased total plant biomass or total plant $\mathrm{N}$ uptake.

Similar relationships between overstory and understory herbaceous species have been explored in other forest types (see [33]). Light availability is a primary limiting resource in understory environments in eastern deciduous forests [34]. Understory plants that persist under low light conditions incorporate various physiological and morphological adaptations, including phenology, leaf morphology, growth form, and photosynthetic pathway [34,35]. A lack of adaptations may explain why understory plants that persist under more open canopies, are substantially diminished as canopy closure increases (e.g., [3]). Moreover, in contrast to our single species experiment, elevated nitrogen availability can influence understory vegetation properties. Gilliam [36], in a review of the literature on understory response to increased nitrogen deposition, indicated that increased nitrogen availability can influence understory vegetation through reductions in biodiversity, altered competitive interactions among species, and enhanced exotic plant invasion.

Discretion in directly applying these results to field situations is recommended as other factors including pine needle litter accumulation and reduced soil temperatures, along with more natural shade characteristics under dense ponderosa pine stands, may alternatively influence Idaho fescue growth patterns from what was observed in this greenhouse experiment. In addition, our single species experiment does not account for the suite of vegetation that make up the understory of these ponderosa pine forests, however Idaho fescue is the dominant species providing over $40 \%$ of the understory cover in this plant association [14] and represents a general response to changing undercanopy resources in this community.

\section{Conclusions}

From these analyses, it was apparent that Idaho fescue plants grown in shaded conditions were less vigorous; exhibiting lower root biomass, shoot biomass, and foliar cover values. This corroborates observational data which indicated that understory vegetation abundance was directly related to soil nitrogen and under-canopy light availability [3]. However, our experiment indicated that only light limited Idaho fescue growth and vigor. Extending our findings more broadly to understory vegetation, we speculate that management activities that focus on reducing tree density should increase undercanopy light and may improve conditions for understory vegetation. However, the recovery of understory species may not occur simply through stand thinning treatments as perennial herbaceous species tend to exhibit poor seed banking abilities [37], and in the absence of sufficient residual understory vegetation, recovery will require off-site sources [38]. Moreover, the potential exists for shifts in understory vegetation to more competitive species [3,39], including exotic annual grasses, which may further limit desired vegetation recovery and exacerbate the degradation in ecosystem resilience.

Acknowledgments: Research was funded by the Oregon Agricultural Experiment Station, the United States Department of Agriculture, Natural Resources Conservation Service, and the Montana Agricultural Experiment Station. We appreciate the efforts of the anonymous reviewers whose comments improved the quality of the manuscript. 
Author Contributions: C.A.C. and W.C.K. were involved in conceiving the experiment, developing appropriate experimental design and analyses, and in writing the manuscript. C.A.C. was responsible for data collection and analyses.

Conflicts of Interest: The authors declare no conflict of interest.

\section{References}

1. Covington, W.; Moore, M. Southwestern ponderosa forest structure: Changes since Euro-American settlement. Forestry 1994, 92, 39-47.

2. Johnson, C.G. Forest Health in the Blue Mountains: A Plant Ecologist's Perspective on Ecosystem Processes and Biological Diversity; Pacific Northwest Research Station PNW-GRR-339; USDA Forest Service: Portland, OR, USA, 1994; p. 23.

3. Carr, C.A.; Krueger, W.C. Understory vegetation and ponderosa pine abundance in eastern Oregon. Rangel. Ecol. Manag. 2011, 64, 533-542. [CrossRef]

4. Clary, W.P.; Kruse, W.H.; Larson, F.R. Cattle grazing and wood production with different basal areas of ponderosa pine. J. Range Manag. 1975, 434-437. [CrossRef]

5. Moore, M.M.; Covington, W.W.; Fule, P.Z. Reference conditions and ecological restoration: A southwestern ponderosa pine perspective. Ecol. Appl. 1999, 9, 1266-1277. [CrossRef]

6. Naumburg, E.; DeWald, L.E. Relationships between Pinus ponderosa forest structure, light characteristics, and understory graminoid species presence and abundance. Forest Ecol. Manag. 1999, 124, 205-215. [CrossRef]

7. Uresk, D.W.; Severson, K.E. Response of understory species to changes in ponderosa pine stocking levels in the black hills. Great Basin Nat. 1998, 58, 312-327.

8. Wienk, C.L.; Sieg, C.H.; McPherson, G.R. Evaluating the role of cutting treatments, fire and soil seed banks in an experimental framework in ponderosa pine forests of the black hills, South Dakota. Forest Ecol. Manag. 2004, 192, 375-393. [CrossRef]

9. Moore, M.M.; Casey, C.A.; Bakker, J.D.; Springer, J.D.; Fule, P.Z.; Covington, W.W.; Laughlin, D.C. Herbaceous vegetation responses (1992-2004) to restoration treatments in a ponderosa pine forest. Rangel. Ecol. Manag. 2006, 59, 135-144. [CrossRef]

10. Naumburg, E.; Dewald, L.E.; Kolb, T.E. Shade responses of five grasses native to southwestern US Pinus ponderosa forests. Can. J. Bot. 2001, 79, 1001-1009.

11. Riegel, G.M.; Miller, R.F.; Krueger, W.C. Understory vegetation response to increasing water and nitrogen levels in a pinus-ponderosa forest in northeastern Oregon. Northwest Sci. 1991, 65, 10-15.

12. Riegel, G.M.; Miller, R.F.; Krueger, W.C. Competition for resources between understory vegetation and overstory pinus-ponderosa in northeastern Oregon. Ecol. Appl. 1992, 2, 71-85. [CrossRef] [PubMed]

13. Riegel, G.M.; Miller, R.F.; Krueger, W.C. The effects of aboveground and belowground competition on understory species composition in a pinus-ponderosa forest. Forest Sci. 1995, 41, 864-889.

14. Johnson, C.; Clausnitzer, R. Plant Associations of the Blue and Ochoco Mountains; USDA Forest Service R6-ERW-TP-036-92; USDA Forest Service: Portland, OR, USA, 1992.

15. Western Regional Climate Center(WRCC). Climatalogical Summary for Seneca, Oregon. Available online: http:/ /www.wrcc.dri.edu/cgi-bin/cliMONtpre.pl?or7675 (accessed on 10 May 2010).

16. Marschner, H. Mineral Nutrition of Higher Plants, 2nd ed.; Academic Press Ltd.: San Diego, CA, USA, 1995.

17. Environmental Systems Research Institute. Arcmap 9.1; Environmental Systems Research Institute, Inc.: Redlands, CA, USA, 2005.

18. Louhaichi, M.; Johnson, D.E.; Borman, M.M. Manual for Assessing Depredation on Grain and Seed Yields, Ver 1.1; Department of Rangeland Resources, Oregon State University: Corvallis, OR, USA, 2003.

19. SAS Institute. Sas for Windows Version 9.1; SAS Institute, Inc.: Cary, NC, USA, 2003.

20. Littell, R.C.; Stroup, W.W.; Milliken, G.A.; Wolfinger, R.D.; Schabenberger, O. SAS for Mixed Models; SAS Institute: Cary, NC, USA, 2006.

21. Allard, G.; Nelson, C.J.; Pallardy, S.G. Shade effects on growth of tall fescue: 1. Leaf anatomy and dry-matter partitioning. Crop Sci. 1991, 31, 163-167. [CrossRef]

22. Boardman, N. Comparative photosynthesis of sun and shade plants. Ann. Rev. Plant Physiol. 1977, 28, 355-377. [CrossRef]

23. Moir, W.H. Influence of ponderosa pine on herbaceous vegetation. Ecology 1966, 47, 1045-1048. [CrossRef] 
24. Lambers, H.; Chapin, F., III; Pons, L. Plant Physiological Ecology; Springer: New York, NY, USA, 1998 ; p. 540.

25. Coyne, P.; Trlica, M.; Owensby, C. Carbon and nitrogen dynamics in range plants. In Wildland Plants: Physiological Ecology and Developmental Morphology; Society for Range Management: Denver, CO, USA, 1995; pp. 59-167.

26. Carr, C.A. An Evaluation of Understory Vegetation Dynamics, Ecosystem Resilience and State and Transition Ecological Theory in an Eastern Oregon Ponderosa Pine Forest. Ph.D Dissertation, PhOregon State University, Corvallis, OR, USA, 2007.

27. Murchie, E.H.; Horton, P. Acclimation of photosynthesis to irradiance and spectral quality in British plant species: Chlorophyll content, photosynthetic capacity and habitat preference. Plant Cell Environ. 1997, 20, 438-448. [CrossRef]

28. Bjorkman, O. Some viewpoints on photosynthetic response and adaptation to environmental stress. In Photosynthesis; Briggs, W.R., Ed.; Alan R. Liss: New York, NY, USA, 1989.

29. Smith, H. Light quality, photoperception, and plant strategy. Ann. Rev. Plant Phsyiol. 1982, 33, 481-518. [CrossRef]

30. Havlin, J.L.; Tisdale, S.L.; Nelson, W.L.; Beaton, J.D. Soil Fertility and Fertilizers, 6th ed.; Prentice-Hall Inc.: Upper Saddle River, NJ, USA, 2007; p. 499.

31. Kaye, J.P.; Hart, S.C. Ecological restoration alters nitrogen transformations in a ponderosa pine bunchgrass ecosystem. Ecol. Appl. 1998, 8, 1052-1060. [CrossRef]

32. Kaye, J.P.; Hart, S.C.; Fule, P.Z.; Covington, W.W.; Moore, M.M.; Kaye, M.W. Initial carbon, nitrogen, and phosphorus fluxes following ponderosa pine restoration treatments. Ecol. Appl. 2005, 15, 1581-1593. [CrossRef]

33. Gilliam, F.S.; Roberts, M.R. The Herbaceous Layer in Forests of Eastern North America; Oxford Universtiy Press: New York, NY, USA, 2003.

34. Nuefeld, H.S.; Young, D.R. Ecophysiology of the herbaceous layer in temperate deciduous forests. In The Herbaceous Layer in Forests of Eastern North America; Gilliam, F.S., Roberts, M.R., Eds.; Oxford Universtiy Press: New York, NY, USA, 2003; pp. 38-90.

35. Pearcy, R.W. Photosynthetic gas exchange responses of Australian tropical forests trees in canopy, gap, and understory micro-environments. Funct. Ecol. 1987, 1, 169-178. [CrossRef]

36. Gilliam, F.S. Response of the herbaceous layer of forest ecosystems to excess nitrogen deposition. J. Ecol. 2006, 94, 1176-1191. [CrossRef]

37. Rees, M. Delayed germination of seeds-A look at the effects of adult longevity, the timing of reproduction, and population age/stage structure. Am. Nat. 1994, 144, 43-64. [CrossRef]

38. Korb, J.E.; Springer, J.D.; Powers, S.R.; Moore, M.M. Soil seed banks in Pinus ponderosa forests in Arizona: Clues to site history and restoration potential. Appl. Veg. Sci. 2005, 8, 103-112. [CrossRef]

39. Page, H.N.; Bork, E.W. Effect of planting season, bunchgrass species, and neighbor control on the success of transplants for grassland restoration. Restor. Ecol. 2005, 13, 651-658. [CrossRef]

(C) 2016 by the authors; licensee MDPI, Basel, Switzerland. This article is an open access article distributed under the terms and conditions of the Creative Commons Attribution (CC-BY) license (http://creativecommons.org/licenses/by/4.0/). 